A Study of Sociological Risk Factors of Youth Suicidal Behaviour and Problem Solving Counselling as a Therapeutic Tool on Prevention - A Study in a Sub-urban Hospital in Sri Lanka by

Eleyaperuma Arachchige Ramani Perera

Thesis Submitted to the University of Sri Jayewardenepura for the award of the Degree of Doctor of Philosophy in Sociology on $31^{\text {st }}$ August 2005 
Dedicated to the memory of my father 
The work described in this thesis was carried out by me under the supervision of Professor S.T. Kathriarachchi of the Department of Psychiatry and Professor D. S. D. J. Abeysekera of the Department of Sociology \& Anthropology of the University of Sri Jayewardenepura and a report on this has not been submitted in whole or in part to any University or any other institution for any other Degree/Diploma.

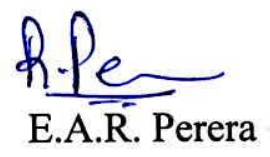


We certify that the above statement made by the candidate is true and that this thesis is suitable for submission to the University for the purpose of evaluation.

$$
\text { S.T-iethriaheh. }
$$

Professor S.T. Kathriarachchi

Department of Psychiatry

University of Sri Jayewardenepura

Date $12108 / 05$

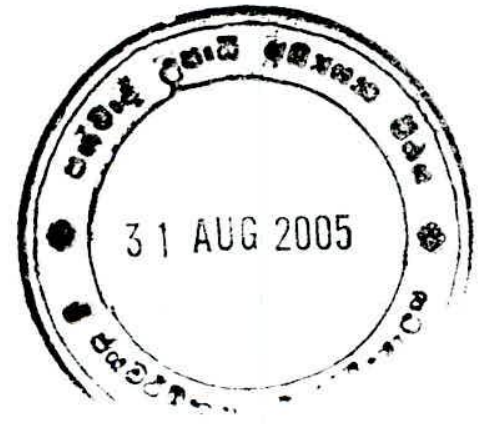

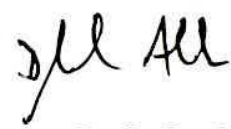

Professor D. S. D. J. Abeysekera

Department of Sociology \& Anthropology

University of Sri Jayewardenepura

Date $31 / 08 / 2005$

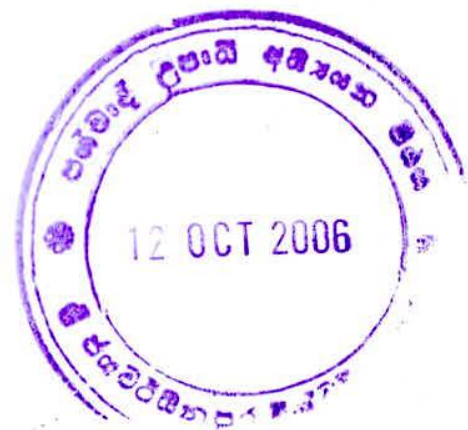




\section{Table of Content}

List of tables

List of Figures $\quad X$

$\begin{array}{ll}\text { Acknowledgements } & \text { XI }\end{array}$

Abstract

Chapter 1

1. INTRODUCTION 1

$\begin{array}{lll}1.1 & \text { Objective of study } & 8\end{array}$

$\begin{array}{lll}1.2 & \text { Organization of chapters } & 10\end{array}$

Chapter 2

2. REVIEW OF SOCIOLOGICAL THEORIES ON SUICIDE AND RISK FACTORS OF SUICIDAL BEHAVIOUR 14

$\begin{array}{lll}2.1 & \text { Sociological theories on suicide } & 14\end{array}$

2.2 Risk factors of suicidal behaviour 32

2.2.1 Unemployment 33

2.2.2 Low socio-economic status 34

$\begin{array}{lll}\text { 2.2.3 Poor educational attainment } & 35\end{array}$

2.2.4 Disruptive family background 36

2.2.5 Broken social relationships and social isolation/alienation 37

2.2.6 Exposure to suicide attempts 38

2.2.7 Access to lethal means $\quad 39$ 
Chapter 3

3. SUICIDAL BEHAVIOUR AND THE PROBLEM OF YOUTH SUICIDE: SRI LANKAN SITUATION IN RELATION TO THE GLOBAL PERSPECTIVE

3.1 Suicidal behaviour in global perspective 44

3.2 The problem of attempted suicide 49

3.3 Methods of suicide and suicide attempts in global perspective 49

$\begin{array}{llr}3.4 & \text { Problem of youth suicide } & 52\end{array}$

3.5 The Sri Lankan situation $\quad 54$

3.5.1 Methods of suicide in Sri Lanka $\quad 57$

Chapter 4

4. SUICIDE PREVENTION MECHANISMS INCLUDING

$\begin{array}{ll}\text { COUNSELLING } & 70\end{array}$

$\begin{array}{lll}4.1 & \text { Suicide prevention mechanisms } & 70\end{array}$

$\begin{array}{lll}\text { 4.2 Counselling as a therapeutic tool } & 82\end{array}$

Chapter 5

$\begin{array}{ll}\text { 5. METHODOLOGY } & 89\end{array}$

$\begin{array}{llr}5.1 & \text { Study design } & 89\end{array}$

$\begin{array}{llr}5.2 & \text { Study setting } & 89\end{array}$ 
$\begin{array}{lll}5.3 & \text { Study population } & 90\end{array}$

5.4 Inclusion criteria and exclusion Criteria 91

$\begin{array}{lll}5.5 & \text { Selection of study sample } & 91\end{array}$

5.6 Allocation of patients to control and experimental groups 93

$\begin{array}{lll}5.7 & \text { Assessment tools } & 93\end{array}$

5.7.1 Mental state examination 93

$\begin{array}{lll}\text { 5.7.2 Suicidal Intent } & 94\end{array}$

5.7.3 Semi structured questionnaire used at the initial interview 95

5.7.3.I Socio-demographic characteristics 96

5.7.3.II Identification of sociological risk factors 96

$\begin{array}{lll}\text { 5.7.4 Individual Visual Analogue Scale } & 103\end{array}$

5.7.5 Semi- structured evaluation questionnaire used in $\begin{array}{ll}\text { the final assessment } & 104\end{array}$

$\begin{array}{llr}5.8 & \text { Ethical clearance } & 105\end{array}$

$\begin{array}{lll}5.9 & \text { Data collection procedure } & 106\end{array}$

$\begin{array}{lll}5.10 & \text { Contacting experts } & 107\end{array}$

$\begin{array}{llr}5.11 & \text { Pilot study } & 108\end{array}$

$\begin{array}{ll}5.12 \text { Counselling sessions as therapeutic tool } & 108\end{array}$

$\begin{array}{llr}5.13 & \text { Dropout rate } & 112\end{array}$

$\begin{array}{llr}5.14 & \text { Limitations } & 112\end{array}$

Chapter 6

$\begin{array}{ll}\text { 6. RESULTS AND DISCUSSION } & 114\end{array}$

6.1 Allocation of patients to control and experimental groups 114 
$\begin{array}{lll}\text { 6.3 Socio-demographic characteristics } & 116\end{array}$

$\begin{array}{lll}\text { 6.3.1 Gender representation } & 116\end{array}$

$\begin{array}{lll}\text { 6.3.2 Age distribution } & 118\end{array}$

$\begin{array}{lll}\text { 6.3.3 Religious representation } & 119\end{array}$

$\begin{array}{lll}\text { 6.3.4 Ethnic representation } & 121\end{array}$

$\begin{array}{lll}\text { 6.3.5 Marital status } & 122\end{array}$

$\begin{array}{lll}\text { 6.4 Identification of sociological risk factors } & 123\end{array}$

$\begin{array}{lll}\text { 6.4.1 Poor educational attainment } & 124\end{array}$

$\begin{array}{lll}\text { 6.4.2 Poor household income level } & 127\end{array}$

6.4.3 Lower level of occupational status of the subject 129

$\begin{array}{lll}\text { 6.4.4 Unemployment } & 132\end{array}$

$\begin{array}{lll}\text { 6.4.5 Pattern of living } & 135\end{array}$

$\begin{array}{ll}\text { 6.4.6 Poor interactions in school } & 136\end{array}$

$\begin{array}{lll}\text { 6.4.7 Poor interaction with the community } & 137\end{array}$

$\begin{array}{lll}\text { 6.4.8 Poor religious practices } & 140\end{array}$

6.4.9 Major difficulties experienced from middle childhood 141

$\begin{array}{ll}\text { 6.4.10 Parental death } & 142\end{array}$

6.4.11 Parental separation, divorce and remarriage 142

$\begin{array}{ll}\text { 6.4.12 Parents being abroad } & 144\end{array}$

6.4.13 Prevalence of alcohol use among subjects 144

$\begin{array}{ll}\text { 6.4.14 Alcoholic behaviour among parents } & 146\end{array}$

$\begin{array}{ll}\text { 6.4.15 Habit of smoking } & 149\end{array}$

$\begin{array}{lr}\text { 6.4.16 Illegal drug use } & 150\end{array}$ 
6.4.18 Unwanted pregnancies

6.4.21 Not having the habit of discussing problems with parents among single subjects

6.4.22 Not having the habit of discussing problems with spouse

6.5.1 Comparison of socio-demographic characteristics between two groups

6.5.2 Pre-assessment on problem solving ability at the inception of the counselling 
Chapter 7

7. CONCLUSIONS AND RECOMMENDATIONS 190

$\begin{array}{lll}7.1 & \text { Conclusions } & 190\end{array}$

$\begin{array}{lll}7.2 & \text { Recommendations } & 194\end{array}$

$\begin{array}{ll}\text { References } & 199\end{array}$

Appendices 


\section{List of Tables}

Table $1 \quad$ - $\quad$ Global suicide rates (per 100,000) by country, year and gender- most recent year available as of May 2003 (Selected countries)

Table $2 \quad$ - $\quad$ Preferred methods of suicides in selected countries

Table 3 - $\quad$ Methods of suicide in Sri Lanka from 1990 to 2002

Table $4 \quad$ - $\quad$ Suicides by religions in Sri Lanka for the period from 1993 to 1998

Table $5 \quad$ - $\quad$ Male: female ratio of suicides in Sri Lanka for the period from 1990 to 1999 .

Table $6 \quad$ - $\quad$ Suicides by ethnicity in Sri Lanka-1993 to 1998

Table $7 \quad$ - $\quad$ Most commonly used suicide methods among youth in Sri Lanka

Table $8 \quad$ - $\quad$ Male suicide rates per 100,000 population by age categories in Sri Lanka

Table $9 \quad$ - $\quad$ Female suicide rates per 100,000 population by age categories in Sri Lanka

Table $10 \quad$ - $\quad$ Preventive interventions at different levels

Table $11 \quad$ - $\quad$ Functional areas of the public health model of suicide prevention - conceptual framework 
Table $12 \quad$ - $\quad$ Predisposing and precipitating conditions

under the antecedent conditions model

Table $13 \quad-\quad$ Age distribution of the sample

Table $14 \quad$ - $\quad$ Marital status representations of the sample and the percentage

Table $15 \quad$ - $\quad$ Level of educational attainment of the sample by sex

Table $16 \quad$ - $\quad$ Household income pattern

Table $17 \quad-\quad$ Occupations of the employed subjects

131

Table $18 \quad-\quad$ Prevalence of alcohol use among the subjects

Table $19 \quad$ - $\quad$ Prevalence of alcohol use among the fathers of the subjects

Table $20 \quad$ - $\quad$ Exposure to suicidal behaviour (completed or attempted)

Table $21 \quad$ - $\quad$ Methods of suicidal attempts in the sample 155

Table $22 \quad$ - $\quad$ Access to means of suicidal attempts by level of resistance

Table $23 \quad$ - $\quad$ Habit of discussing problems with parents 
Table $25 \quad$ - $\quad$ Major precipitating factors for suicidal attempts of the sample

Table $26 \quad$ - Ninety five percent confidence interval for the prevalence of the risk factors

Table $27 \quad$ - $\quad$ Comparison of the problem solving ability of the subjects in both groups: initial assessment using Individual Visual Analogue Scale

Table $28 \quad-\quad$ Comparison of the problem solving ability of the subjects in both groups: final assessment using Individual Visual Analogue Scale

Table $29 \quad$ - $\quad$ Results of the semi-structured questionnaire used in the final assessment 


\section{List of figures}

Figure $1 \quad$ - $\quad$ Varying levels of integration - regulation

Figure $2 \quad$ - $\quad$ Theoretical relationship between potential suicide and network density

Figure $3 \quad-\quad$ Evolution of global suicide rates $1950-1995$ (per 100,000)

Figure $4 \quad$ - $\quad$ Suicide rates per 100,000 population in Sri Lanka during selected years From 1880 to 2000

Figure $5 \quad$ - $\quad$ Gender representation of the sample

Figure $6 \quad$ - $\quad$ Religious representation of the total sample and catchment area

Figure $7 \quad$ - $\quad$ Level of education of the sample

Figure $8 \quad$ - $\quad$ Household income distribution pattern 


\section{Acknowledgements}

I completed my field research and the thesis directly under the supervision of Professor Samudra Kathriarachchi, Department of Psychiatry and Professor Dayalal Abeysekera, Department of Sociology and Anthropology of the University of Sri Jayawardenepura. I am deeply indebted to my supervisors for providing timely and instructive comments and evaluation at every stage of the study. They provided insights that guided and challenged my thinking, substantially improving my thesis.

My special thanks go to Dr. D.R. Gabadage, the Director of the Homagama Base Hospital and Consultant Physician Dr. Mrs. B. Lamabadusuriya for granting me permission to carry out the field survey and para-medical staff of the Homagama Base Hospital for their support.

I am deeply grateful to the patients who participated in the Study and their family members for their assistance.

I extend my warm appreciation to Dr. Swarnalatha Perera, Head of the Department of Sociology and Anthropology, and Professor Tennyson Perera of the Department of Sociology and Anthropology, for their encouragement and guidance to enhance my knowledge base to complete the thesis in a challenging manner.

I thank consultants and medical officers in the field of psychiatry as well as academics in the fields of sociology and psychology; especially, Professor Nalaka Mendis, 
Dr. Iyanthika Medagama, Dr. Yasanjalee Perera, Dr. Praneeth Abeysundara, Dr. Jayantha Jayasiri, Mr. Sunil Ratnayake and Psychologist T. Suveendran for their warm and gracious contribution in providing the opportunity to discuss and share knowledge.

I appreciate the support and generous assistance given by the librarians in the University of Sri Jayawardenepura, National Institute of Social Development, World Health Organization Colombo office, National Museum, Family Health Bureau and University of Colombo. In addition, I thank Officials of the Department of Police, the Department of Census and Statistics, and the Urban Development Authority for providing data.

I specially thank Dr. Bilesha Perera for the warm, open and gracious contribution in responding to my request and assisting me to obtain literature from the libraries in the Indiana University of the United States of America. Also my special thanks go to Mr. Sisira Chandrasekera of Hammersmith \& West London College in the United Kingdom for sending some textbooks. I greatly appreciate the assistance given by my niece Dilanki in data tabulation work.

I wish to express my warm gratitude also to several longtime friends and colleagues whose encouragement and continued support became a strong motivational factor.

I specially thank my husband and my son, for their patience, encouragement and assistance, which gave me tremendous courage and the ability to devote maximum time for the study. 


\title{
A Study of Sociological Risk Factors of Youth Suicidal Behaviour and Problem Solving Counselling as a Therapeutic Tool on Prevention -
}

\author{
A Study in a Sub-urban Hospital in Sri Lanka
}

\section{Eleyaperuma Arachchige Ramani Perera}

\begin{abstract}
Suicidal behaviour has been a major concern in all societies and literature on suicide has been found as far back as the $5^{\text {th }}$ century and was later popularized by sociological work of Emile Durkheim. Suicidal behaviour has become a public health issue and approximately one million people would have committed suicide in the year 2000 globally. Suicide and attempted suicide rates in Sri Lanka fall within the highest group of countries in the world. There were only a few descriptive studies that investigated the sociological risk factors as well as counselling as preventive tool for youth suicidal behaviour in the country. This Study included two components. The first was designed to identify the demographic profile and sociological risk factors of the Study sample, which is a descriptive study. The second part was designed to test effectiveness of problem solving counselling as a therapeutic tool in prevention of youth suicidal behaviour, which is a comparative study. In this second part, the sample is divided into two groups, experimental and control and offered four sessions of problem solving counselling to the experimental group. The Homagama Base Hospital was selected and a sample of 124 cases admitted was interviewed. Buddhists (88.7 percent) and Sinhala
\end{abstract}


(96.0 percent) predominate the sample comparable to catchment area and the national data. Of the total, 66.9 percent were women and 71.8 percent were single. Results indicated that the age group of 15 to 24 years is a vulnerable group for suicidal behaviour in sub-urban areas of Sri Lanka and that females are more susceptible in this age group. Risk factors such as poor interaction with father (79.8 percent), poor educational attainment (66.1 percent), poor interaction with mother (53.9 percent), family conflicts (52.4 percent), exposure to suicidal behaviour of close associates (48.3 percent), poor interaction with neighbors (43.5 percent), unemployment (41.9 percent), poor interaction with friends (39.5 percent), essay access to pesticide (36.3 percent), easy access to medicinal drugs (35.6 percent), mother being abroad (26.6 percent), break-up of love affairs (26.6 percent) and alcohol behaviour of parents ( 24.2 percent) were the risk factors identified in this Study. The Study found that four sessions of problem solving counselling conducted by the same therapist for each subject have significantly improved the problem solving skills and coping strategies of youth with suicidal behaviour. Subjects in the experimental group had shown progressive behaviour in terms of coping stressful life events. The Study confirms that problem solving counselling found to be an effective therapeutic tool in reducing youth suicidal thoughts and behaviour in sub urban communities in Sri Lanka, indicating the introduction of community-wide counselling facilities at the community level would be an important aspect in reducing youth suicidal behaviour. Counselling needs to be made easily available and accessible to the youth to establish therapeutic relationships in medical institutions and in the community. 